Meta

Journal des traducteurs

Translators' Journal

\title{
Teaching Translation Theory
}

\section{Peter Fawcett}

Volume 26, numéro 2, juin 1981

URI : https://id.erudit.org/iderudit/002734ar

DOI : https://doi.org/10.7202/002734ar

Aller au sommaire du numéro

Éditeur(s)

Les Presses de l'Université de Montréal

ISSN

0026-0452 (imprimé)

1492-1421 (numérique)

Découvrir la revue

Citer cet article

Fawcett, P. (1981). Teaching Translation Theory. Meta, 26(2), 141-147.

https://doi.org/10.7202/002734ar

Ce document est protégé par la loi sur le droit d'auteur. L'utilisation des services d'Érudit (y compris la reproduction) est assujettie à sa politique d'utilisation que vous pouvez consulter en ligne.

https://apropos.erudit.org/fr/usagers/politique-dutilisation/
Cet article est diffusé et préservé par Érudit.

Érudit est un consortium interuniversitaire sans but lucratif composé de l’Université de Montréal, l'Université Laval et l'Université du Québec à Montréal. Il a pour mission la promotion et la valorisation de la recherche. https://www.erudit.org/fr/ 


\section{Teaching Translation Theory}

Peter Fawcett

In spite of the increasing volume of research into translation theory, there still seem to be few attempts to set up separate formal courses in the subject.

The reasons for this reluctance are not hard to imagine. They can be summarised under the following headings:

a) the nature of the published material :

i. much of this consists of separate articles or collections of articles, many of which qualify for Levy's description of "Essayistische Plaudereien"';

ii. much of the material is hard to obtain, either because it comes from Eastern Europe with its different publishing practices, or because it has not been translated and is therefore accessible only to someone who can read all of the following: German, Russian, Spanish, Italian, French, Czech, Latin, and possibly also Rumanian, Hungarian, Georgian...;

$b$ ) the breadth of background knowledge needed, which involves an understanding of historical method, all the branches of linguistics (structural, comparative, psycho-, socio-, text and computer linguistics), literary criticism, hermeneutics, and possibly ethnography, as well as a thorough grasp of all the literature written on the subject itself;

c) the apparently unsatisfactory state of translation theory at the present time, which is characterised by : unresolved theoretical conflict, alternation between excessive abstraction and excessive detail ${ }^{2}$, triviality of example and apparent absence of transfer;

d) pedagogical uncertainty concerning not only what and how to teach, but also where. Attempts to integrate theory into the standard translation class fall foul of certain constraints :

i. the need to get a translation done (students grow impatient if discussion too frequently prevents actual translation from being done);

ii. the time-consuming need to return and discuss large quantities of corrected translations;

1. Jiri Levy, Die literarische Übersetzung. Theorie einer Kunstgattung, Frankfurt, Athenaum, 1969 , p. 13.

2. Wolfram, Wilss, Übersetzungswissenschaft. Probleme und Methoden, Stuttgart, Klett, 1977, p. 99 and 225 . 
iii. the random nature of text selection which prevents a unified teaching of theory.

It is scarcely surprising, then, if attempts to teach theory are quietly abandoned, or if students become textbound (a concept which some have even erected into a theoretical principle) ${ }^{3}$, commanding only a narrow range of translation techniques and only too happy, as professionals, to justify rough and literal translation on the grounds of insufficient time, an undemanding receptor, the need to avoid subjective interpretations, or the unexamined principle (proclaimed by many a teacher of translation, too) that deviation from literalness alters the meaning.

What becomes, in this context, of the declaration that "Every translator is an artist" 4 ?

In the meantime, the translation class proceeds along the sole theoretical principle of "as literal as possible, as free as necessary", neglectful of any factor other than the text, and translation quality assessment proceeds according to the lordly, but completely unexplained, whimsy of "It doesn't sound right."

Not only is the translation class thereby deprived of much-needed pedagogical variety, but a precious occasion is lost to teach the importance of systematic solution of problems and, even more vital to translation, systematic testing of solutions. For, what Baumol says of business management is also true of translation: "The foregoing does not mean that... the analyst even pretends to be able to find the best of all possible decisions. The data are too inaccurate, the tools of analysis are often too blunt... Nevertheless, an analysis which is specifically designed to look for optimal decisions, crude and approximative though it may be, is very likely to do much better than the workable but relatively arbitrary rules of thumb of obscure origin..." 5

And when it comes to rules of thumb, we would do well to heed the words of Hirsch: "The important point about a rule of thumb is that it is not a rule" 6 .

Of the problems relating to translation theory, some are very real (there is a desperate need for the major texts to be made available in translation and for monographs explaining the main contributory disciplines in terms of their relevance to translation), others are trivial (unresolved theoretical conflict should not be a source of anxiety), whilst others arise from a misconception (the so-called absence of transfer ("solutions with no systematic methods of solution") ? exists only at the lowest linguistic level, where the creative and idiolectic nature of language make it inevitable. Translation belonging to hermeneutics, "The proper realm for generalisations... turns out to be the realm of prin-

3. K. Reichert, quoted in Wilss, op. cit., p. 172.

4. György Radó, Babel, 25, 4, 1979, p. 188.

5. W. Baumol, Economic Theory and Operations Analysis, 3rd ed., Englewood Cliffs, New Jersey, Prentice-Hall, 1972, p. 4.

6. E. D. Hirsch, Validity in Interpretation, New Haven and London, Yale U.P., 1967, p. 203.

7. George Steiner, After Babel. Aspects of Language and Translation, London, Oxford U.P., 1975 , p. 275. 
ciples..." 8 , processes and frameworks, which, for all their abstraction, are a vital part of translation. The main reason why transfer of knowledge is looked for at the wrong level in translation arises from its hybrid role as an exercise to be taught and learnt for itself and as a technique for teaching and learning a foreign language.)

Problems relating to the pedagogy of translation theory can be solved by the application of an appropriate method, and it is to this that the remainder of this article is devoted.

\section{A FRAMEWORK FOR OBJECTIVES}

The standard procedures of educational technology developed over the last few decades are well catalogued in Rowntree $(1974)^{9}$. Of the four stages he describes in the process of developing a syllabus, only the first two (Objectives and Design of Learning) will concern us here, and, more specifically, the kind of objectives that can be written and the types of sequence that can be used.

Of the three kinds of objective distinguished by Bloom, (1956) ${ }^{10}$ and Krathwohl, Bloom and Masia (1964) ${ }^{11}$, the cognitive and affective are relevant to translation. For the affective domain, which must not be neglected, the most useful levels are "awareness" and "willingness". Any examination should be devised to test achievement of these objectives.

For the cognitive domain, one can either make use of the complete taxonomy designed by Bloom, with its six levels, or, more conveniently, the three levels suggested by Stones (1972) ${ }^{12}$ : recall, identify, apply.

\section{AFFECTIVE DOMAIN}

In the affective domain, the following represent some of the objectives to be achieved :

- awareness of the complexity of the translation process;

- awareness and tolerance of ambiguity, connotation and register;

- awareness of and willingness to use the whole spectrum of translation strategies and techniques;

8. E. D. Hirsch, op cit., p. 207.

9. Derek Rowntree, Educational Technology in Curriculum Development, London, Harper and Row, 1974.

10. B. S. Bloom, (ed.), Taxonomy of Educational Objectives: Cognitive Domain, New York, David McKay, 1956.

11. D. R. Krathwohl, S.B. Bloom and B. Masia, Taxonomy of Educational Objectives: Affective Domain, New York, David McKay, 1964.

12. E. Stones, Educational Objectives and the Teaching of Educational Psychology, London, Methuen, 1972. 
- willingness to indulge in lateral thinking, to use yes-no-po ${ }^{13}$ and to be discontent with intuitions that have not been systematically validated;

- willingness to insist on precision in the thinking of those who correct their translations.

\section{COGNITIVE DOMAIN}

Of the various stages involved in the writing of objectives in this domain, only two need concern us here : defining the knowledge to be acquired and the actual writing of the objectives.

\section{WHAT TO TEACH}

A succinct, but incomplete, account of the topics involved is provided by Koller (1978) ${ }^{14}$ :

- Applied translation theory : preparation of text books and hand books;

- Specific translation theory: application of the results of general theory to specific language pairs and text types;

- General translation theory : models of translation translatability strategies and techniques text linguistics equivalence

This list needs to be supplemented by the following:

history of translation theory and practice translation rules special forms of translating (intralingual, intersemiotic, transcription, etc.) special modes of translating (dubbing, interpreting) machine translation translation quality assessment contributory disciplines

\section{OBJECTIVES}

A small selection of these topics will serve to show what kinds of objective can be written and how the process is valuable in helping to:

13. E. de Bono, Po: Beyond Yes and No, Harmondsworth, Penguin Books, 1973.

14. Werner Koller, "Aquivalenz in kontrastiver Linguistik und Übersetzungswissenchaft», in L. Grähs, G. Korlén and B. Malmberg, (eds.), Theory and Practice of Translation Berne, Lang, 1978, p. 69-92. 
- define the scope of each topic

- suggest ways of varying teaching techniques

- establish the manner of examination assessment

\section{Topic: History of Theory and Practice}

- recall the major schools of thought throughout history

- evaluate the possibility of achieving a coherent description and conceptual framework for the history of translation

- demonstrate awareness of the culture-bound nature of translation theory and practice by :

- identifying the cultural pressures involved in the following translation - identifying the different treatments that might have been given to the following texts in the following periods

- enumerating the cultural factors which influence modern translation theory

\section{Topic: Models of translation}

- recall major models of the process and evaluate their usefulness

- identify the model which seems to have presided over the following translations

- show how different models would handle the following

- recall psychological/sociological theories related to translator/receptor and show how they might influence the translation of the following text

\section{Topic : Text Linguistics}

- recall major theories of text typology

- describe major features of a given text type

- identify in a given translation the presence/absence of translation techniques appropriate to text type

- demonstrate how changes in TL publisher, intention, audience would influence translation of the following

The aim would be to arrange a complete set of such topics into the proper hierarchy (Gagné, 1965) ${ }^{15}$, but present state of research does not allow this.

\section{SEQUENCING}

An analysis of major publications on translation theory reveals a wide variety of approaches. Smith (1958) ${ }^{16}$, Brower (1959) ${ }^{17}$, and Arrowsmith and Shattuck (1964) ${ }^{18}$ are compilations rightly described by Levy as "methodologisch recht uneinheitlich" 19 and hence of little help to the syllabus designer.

15. R. M. Gagné, The Conditions of Learning, New York, Holt, Rinehart and Winston, 1965.

15. A. H. Smith, (ed.), Aspects of Translation, London, Secker and Warburg, 1958.

17. Reuben A. Brower, (ed.), On Translation, Cambridge, Mass., Harvard U.P., 1959.

18. William Arrowsmith and Roger Shattuck, (eds.), The Craft and Context of Translation, Austin, University of Texas Press, 1961

19. Levy, op. cit., p. 15. 
A more unified approach is suggested by Catford $(1965)^{20}$, and Wilss $(1978)^{21}$, both of whom structure their books around central topics of translation theory. An analysis of Wilss is to be found in Hartmann (1979) 22 . Catford moves from definitions (types of translation, equivalence) to special kinds of translation, translation shifts and the problem of translatability. For pedagogical purposes, the book is limited by its restricted linguistic base, its many omissions, and the limited usefulness of much of the discussion of special kinds of translation.

Another candidate for sequencing is to be found in the mode of presentation adopted by Nida and Taber (1964) ${ }^{23}$ and Levy (1969), both of whom discuss each phase of the translation process in turn.

A third organising principle is provided by the kind of approach suggested by Savory (1957) ${ }^{24}$, Jumpelt $(1961)^{25}$ and Reiss $(1971,1976)^{26}$, where translation techniques and problems are considered according to text type.

Finally, we have the approach adopted by Kloepfer $(1967)^{27}$ who looks at translation strategy throughout history, and Kelly $(1979)^{28}$, who analyses the way in which major translation concepts have been handled at various times.

\section{ASSESSMENT}

The historical approach, fascinating though it may be to the expert, is likely to be exasperating for most students, whilst the text type approach, though it may fit in with the structuring of translation classes, would involve too much repetition. The phase analysis might seem worthwhile as a sequencing principle, but would, in fact, result in the translation theory class falling too much out of step with the practical translation class.

This effectively leaves us with the approach via major topics, but still does not solve the problem of sequence, since the central topics could be arranged logically or psychologically, two modes which, as Rowntree says ${ }^{29}$, often conflict.

The logical order would seem to be : $1^{\circ}$ historical conflict over strategy and possibility of translation; $2^{\circ}$ attempts to overcome the problem by defining

20. J. C. Catford, A Linguistic Theory of Translation, London, Oxford U.P., 1965.

21. Wilss, op. cit

22. R.R.K. Hartmann, Babel, 25, 2, 1979, p. 102-104.

23. Eugene A. Nida and Charles R. Taber, The Theory and Practice of Translation, Leiden, Brill, 1974.

24. Theodore H. Savory, The Art of Translation, Boston, The Writer, 1968

25. Rudolf W. Jumpelt, Die Übersetzung naturwissenschaftlicher and technischer Literatur, Berlin, Langenscheidt, 1961.

26. Katharina Reiss, Möglichkeiten und Grenzen der Übersetzungs-Kritik, Munich, Max Hueber, 1971.

- Texttyp und Übersetzungsmethode. Der operative Text, Stuttgart, Scriptor, 1976.

27. Rolf Kloepfer, Die Theorie der literarischen Ubersetzung, Munich, Wilhelm Fink, 1967.

28. Louis Kelly, The True Interpreter. A History of Translation Theory and Practice in the West, Oxford, Basil Blackwell, 1979.

29. D. Rowntree, op. cit., p. 77. 
a) the nature of equivalence, $b$ ) strategies and techniques needed to achieve equivalence, applied to $c$ ) various text types and translation modes.

However, the need for translation theory studies to bear immediate fruit in practice suggests a psychological order which is the reverse of the above and which would represent an adaptation of backward chaining ${ }^{30}$, in which a series of carefully chosen translations, seen as attempts to solve a specific problem, would lead to discussion going backwards from $2^{\circ}$ to $1^{\circ}$ above.

In fact, given the tightly-knit nature of translation theory, in which every concept depends upon and leads back to the others, this sequence would have to be grafted onto a spiral sequence ${ }^{31}$, in which a first series of texts would lead to a conceptual map of the field which would then be explored in increasing detail on a second and third series of texts.

Such a course would be appropriate for the undergraduate level. For postgraduate students, it might be preferable to construct a course laying the basis for research activity. This would involve three parts : $1^{\circ}$ a short series of intensive lectures to present the whole field of translation theory; $2^{\circ}$ a critical study of translation research using, for example, some of the papers presented in Interlinguistica $(1971)^{32}$ as a basis for discussion; $3^{\circ}$ an individual research project related to some aspect of translation theory or practice.

\section{CONCLUSION}

The numerous possibilities and problems reveal the complexity of planning and organisation needed to set up a course in translation theory, whilst the long list of topics involved reveal the need for such a course to be a separate component of any curriculum intended to produce professional translators and interpreters and to prepare much-needed researchers.

32. K.-R. Bausch and H.-M. Gauger, (eds.), Interlinguistica. Sprachvergleich und Übersetzung. Festschrift zum 60 Geburtstag von Mario Wandruszka, Tübingen, Max Niemeyer, 1971. 